\title{
Milk production and composition of mid-lactation cows consuming perennial ryegrass- and chicory-based diets
}

\author{
S. K. Muir, ${ }^{1}$ G. N. Ward, and J. L. Jacobs \\ Department of Environment and Primary Industries, 78 Henna Street, Warrnambool, Victoria 3280, Australia
}

\begin{abstract}
Dry matter intakes (DMI), nutrient selection, and milk production responses of dairy cows grazing 3 herbage-based diets offered at 2 allowances were measured. The 2 allowances were 20 (low) and 30 (high) $\mathrm{kg}$ of dry matter $(\mathrm{DM}) / \mathrm{cow}$ per day and these were applied to 3 herbage types: perennial ryegrass (PRG) and chicory $(\mathrm{CHIC}+)$ monocultures and a mixed sward of chicory and perennial ryegrass (MIX). The CHIC+ diet was supplemented with alfalfa hay (approximately $2 \mathrm{~kg}$ of DM/cow per day) to maintain dietary neutral detergent fiber (NDF) concentration and all diets were supplemented with energy-based pellets ( $6 \mathrm{~kg}$ of DM/ cow per day). Holstein-Friesian dairy cows averaging $136 \pm 30 \mathrm{~d}$ in milk were allocated to 4 replicates of the 6 treatments using stratified randomization procedures. Cows were adapted to their experimental diets over a 14-d period, with measurements of DMI, milk yield, and composition conducted over the following 10 d. Herbage DMI was lowest (12.8 vs. $14.0 \mathrm{~kg}$ of $\mathrm{DM} / \mathrm{d}$ ) for CHIC+ compared with the MIX and PRG, although total forage intake (grazed herbage plus hay) was similar (14.0 to $15.0 \mathrm{~kg}$ of $\mathrm{DM} / \mathrm{d}$ ) across the 3 treatments. Milk production, milk protein, and milk fat concentrations were not different between herbage types. Grazed herbage DMI increased with increasing herbage allowance and this was associated with increased milk protein concentration (3.23 to 3.34\%) and total casein production (41.7 to $43.6 \mathrm{mg} / \mathrm{g}$ ). Concentrations of polyunsaturated fatty acids in milk fat, particularly linoleic acid, were increased in milk from cows offered the CHIC+ or the MIX diets, indicating potential benefits of chicory herbage on milk fatty acid concentrations. Although feeding CHIC+ or MIX did not increase milk yield, these herbage types could be used as an alternative to perennial ryegrass pasture in spring.
\end{abstract}

Key words: chicory, perennial ryegrass, milk production, milk composition

Received June 25, 2013.

Accepted October 22, 2013.

${ }^{1}$ Corresponding author: stephanie.muir@depi.vic.gov.au

\section{INTRODUCTION}

Grazed herbage comprises the major component of dairy cow diets in many temperate Australasian dairy systems (Doyle et al., 2000; Chapman et al., 2008) where perennial ryegrass (PRG; Lolium perenne L.) is the dominant species (Waghorn and Clark, 2004; Chapman et al., 2006). The highly seasonal growth pattern of PRG, particularly with increasingly variable weather conditions, is considered a limitation to increasing supply of homegrown forage in dry land dairy systems in southern Australia (Chapman et al., 2006, 2008). Forage herbs, such as chicory (Cichorium intybus L.) provide options to improve DM and nutrient intake in late spring, summer, and autumn (Chapman et al., 2008). Chicory is a summer-autumn active herb with high DM yield potential and a more uniform ME and CP than PRG (Waugh et al., 1998).

Relatively few studies have evaluated milk production and composition responses to feeding chicory to dairy cows. Two studies (Waugh et al., 1998; Chapman et al., 2008) suggest increases in milk yield with chicory compared with perennial ryegrass, during summer and autumn. Also, Li and Kemp (2005) reported that when dairy cows grazed chicory (cultivar Puna), milk production increased compared with cows grazing mixed pastures of primarily orchardgrass (Dactylis glomerata L.) and white clover (Trifolium repens L.). Further, Minnee et al. (2012) showed that when the estimated ME of PRG was low $(9.6 \mathrm{MJ} / \mathrm{kg}$ of $\mathrm{DM})$ compared with chicory $(12.3 \mathrm{MJ} / \mathrm{kg}$ of $\mathrm{DM})$ and the proportion of chicory in a perennial ryegrass-based diet was increased ( 0 to $40 \%$ chicory), milk yield increased from 9.9 to $12.6 \mathrm{~kg} /$ cow per day. In contrast, when the estimated ME of the PRG was higher $(10.5 \mathrm{MJ} / \mathrm{kg}$ of $\mathrm{DM})$, increasing the proportion of chicory in the diet increased milk yield from 14.9 to $15.7 \mathrm{~kg} / \mathrm{cow}$ per day.

$\mathrm{Li}$ and Kemp (2005) commented that the high DM digestibility of chicory and its fast rumen clearance rate provide opportunity for improved voluntary feed intake and production. Conversely, Collins and McCoy (1997) and Tinworth et al. (1999) suggested that the high moisture content of chicory may negatively affect voluntary feed intake. However, this is likely to be sea- 
sonally dependent, with DM content ranging from as low as $8 \%$ in winter to over $20 \%$ in summer (J. L. Jacobs, unpublished data). Any effects on the intakes of $\mathrm{DM}$, estimated $\mathrm{ME}$, or other nutrients (including lipid) from incorporating chicory in cow diets may affect the composition of milk fat and protein. It is considered that appropriate levels of chicory allocation to maximize intake and increase milk production while maintaining rumen health (and desirable milk composition) have not been determined for lactating dairy cattle. The hypotheses tested in this experiment were that (1) cows grazing a monoculture of chicory (supplemented with alfalfa hay and concentrate pellets) or a mixture of chicory and PRG (supplemented with concentrate pellets) would produce more milk than those fed PRG and pellets due to higher DM and nutrient intakes; (2) offering these 3 diets at a higher herbage allowance would increase milk production through increases in DM and nutrient intake, irrespective of herbage type; and (3) replacing perennial ryegrass with chicory in the diet would affect milk fat and protein composition.

\section{MATERIALS AND METHODS}

\section{Experimental Design}

The experiment was conducted on a commercial dairy farm located near Terang $\left(38^{\circ} 14^{\prime} \mathrm{S}, 142^{\circ} 55^{\prime} \mathrm{E}\right)$ in southwest Victoria, Australia, during the spring (October-November 2012). All procedures were conducted in accordance with the Australian Code of Practice for the Care and Use of Animals for Scientific Purposes (National Health and Medical Research Council, 2004). Approval to proceed was obtained from the Department of Environment and Primary Industries (DEPI) Agricultural Research and Extension Animal Ethics Committee (Horsham, Victoria, Australia).

The grazing treatments were as follows:

1. CHIC+: cows grazed a monoculture of chicory supplemented with $2 \mathrm{~kg}$ of DM/cow per day of alfalfa (Medicago sativa L.) hay fed in a trough in the paddock (50\% after each milking) plus pellets fed at $6 \mathrm{~kg}$ of $\mathrm{DM} / \mathrm{cow}$ per day (fed in the dairy; $50 \%$ at each milking);

2. MIX: cows were offered a mixed sward of PRG and chicory ( $50: 50$ DM) supplemented with pellets as above;

3. PRG: cows were offered a monoculture of PRG supplemented with pellets as above.

Each herbage type was offered at 2 allowances, nominally 20 and $30 \mathrm{~kg}$ of $\mathrm{DM} /$ cow per day, with allowance based on DM to ground level. This provided a total of 6 dietary regimens, namely, $\mathrm{CHIC}+20, \mathrm{CHIC}+30$, MIX20, MIX30 PRG20, and PRG30. The study was carried out as a split-plot design, with herbage type as the main plot and pasture allocation as the subplot. Each of the dietary treatments was replicated 4 times. In this design, the replicates were a single paddock and the 18 animals grazing that paddock, the plots were a strip of a given herbage type and the 6 animals grazing that strip, and the subplots were a sub-strip (allowance level) and the 3 animals grazing that sub-strip.

Pellets contained (as a \% of DM) wheat grain $(35.6 \%)$, maize grain $(25 \%)$, canola meal $(10 \%)$, lupines $(7 \%)$, mill run $(15 \%)$, lime $(3 \%)$, molasses $(2 \%)$, pellet binder (1\%, Fluidarom 1025; AusPac Ingredients Pty Ltd., Tamworth, New South Wales, Australia), magnesium sulfate $(0.5 \%)$, acid buffer (0.4\%, Acid Buf; Celtic Sea Minerals, Co. Cork, Ireland), betaine $(0.18 \%$, Bos Koolus; Feedworks Pty Ltd., Romsey, Victoria, Australia), Elitox (0.18\%; Impextraco NV, Heist-op-den-Berg, Belgium), mineral premix (0.09\%), and Agolin (0.01\%; Agolin SA, Bière, Switzerland). Elitox is used to reduce mycotoxic stress by binding and inactivating mycotoxins. Agolin is an essential oil rumen modifier used as an alternative to ionophores. The mineral premix contained vitamins $\mathrm{D}_{3}, \mathrm{E}$, and $\mathrm{A}$, cobalt, selenium, iodine, manganese, zinc, copper, calcium, wheat pollard, oil, and antioxidants. The nutritive characteristics of all dietary ingredients are given in Table 1.

\section{Site and Establishment}

The soil is described as a brown chromosol derived from quaternary basalt. The soil has an A1 horizon of 0 to $25 \mathrm{~cm}$, consisting of a fine sandy clay loam with an A2 from 25 to 40 of fine sandy clay loam with many (50\%) ferruginous concretions $(2-10 \mathrm{~mm}$ size). The B horizon $(40-140 \mathrm{~cm})$ is a light to medium clay with a very firm consistency.

In October 2011, a series of forage treatment areas were established based on monocultures of perennial ryegrass (Lolium perenne L. cultivar Halo AR37) and chicory (Cichorium intybus L. cultivar Choice) or a mixed sward of perennial ryegrass and chicory. Following cultivation, 4 paddocks each of 3 ha were split equally into 3 areas running the length of the paddock. Within each paddock, strips were randomly allocated and sown to either a mixture of chicory $(5 \mathrm{~kg} / \mathrm{ha})$ and perennial ryegrass $(25 \mathrm{~kg} / \mathrm{ha})$ or a monoculture of each forage (PRG: $25 \mathrm{~kg} / \mathrm{ha}$; chicory: $10 \mathrm{~kg} / \mathrm{ha}$ ). A further 2 paddocks (each of 3 ha) with an area of 6 ha were sown with a mixture of perennial ryegrass and chicory, and 1 paddock ( 3 ha) with a monoculture of perennial ryegrass. 
Table 1. Dry matter, CP, ADF, NDF, estimated ME, and FA composition for chicory (CHIC), mixed perennial ryegrass and chicory (MIX), perennial ryegrass $(\mathrm{PRG})$, alfalfa hay, and pellets ${ }^{1}$

\begin{tabular}{|c|c|c|c|c|c|}
\hline Composition & $\mathrm{CHIC}$ & MIX & PRG & Alfalfa hay & Pellets \\
\hline $\mathrm{CP}, \mathrm{g} / \mathrm{kg}$ & $137 \pm 5.3$ & $148 \pm 11.2$ & $133 \pm 12.5$ & $171 \pm 2.1$ & $150 \pm 1.0$ \\
\hline $\mathrm{ADF}, \mathrm{g} / \mathrm{kg}$ & $225 \pm 2.5$ & $283 \pm 6.8$ & $306 \pm 15.1$ & $352 \pm 5.0$ & $70 \pm 0.8$ \\
\hline Estimated ME, MJ/kg & $11.3 \pm 0.14$ & $11.2 \pm 0.05$ & $11.2 \pm 0.20$ & $8.2 \pm 0.6$ & $13.1 \pm 0.2$ \\
\hline \multicolumn{6}{|l|}{$\mathrm{FA}, \mathrm{mg} / \mathrm{g}$} \\
\hline C14:0 & $0.12 \pm 0.054$ & $0.12 \pm 0.029$ & $0.13 \pm 0.017$ & $0.09 \pm 0.013$ & $0.03 \pm 0.037$ \\
\hline $\mathrm{C} 17: 0$ & $0.08 \pm 0.016$ & $0.13 \pm 0.017$ & $0.14 \pm 0.017$ & $0.06 \pm 0.021$ & $0.00 \pm 0.000$ \\
\hline C18:0 & $0.28 \pm 0.042$ & $0.30 \pm 0.017$ & $0.35 \pm 0.106$ & $0.43 \pm 0.043$ & $0.61 \pm 0.014$ \\
\hline cis-9 C18:1 & $0.43 \pm 0.087$ & $0.39 \pm 0.046$ & $0.34 \pm 0.053$ & $0.25 \pm 0.051$ & $10.34 \pm 0.224$ \\
\hline cis-11 C18:1 & $0.04 \pm 0.031$ & $0.06 \pm 0.024$ & $0.03 \pm 0.035$ & $0.00 \pm 0.000$ & $0.85 \pm 0.036$ \\
\hline C18:2n-6 & $5.38 \pm 0.179$ & $4.12 \pm 0.517$ & $2.10 \pm 0.197$ & $1.24 \pm 0.195$ & $17.56 \pm 0.068$ \\
\hline C20:0 & $0.13 \pm 0.034$ & $0.12 \pm 0.031$ & $0.11 \pm 0.021$ & $0.12 \pm 0.016$ & $0.14 \pm 0.009$ \\
\hline C18:3n-3 & $10.67 \pm 1.396$ & $12.71 \pm 1.249$ & $11.10 \pm 1.281$ & $0.96 \pm 0.039$ & $1.28 \pm 0.017$ \\
\hline
\end{tabular}

${ }^{1}$ Data are means \pm SD of daily samples collected during the measurement period.

Herbicide (Broadstrike, $40 \mathrm{~g} / \mathrm{ha}, 800 \mathrm{~g}$ of flumetsulam/kg; Dow AgroSciences Australia Ltd., Frenchs Forest, New South Wales, Australia) plus Uptake Spraying Oil $(500 \mathrm{~mL} / 100 \mathrm{~L}$ of water, $582 \mathrm{~g}$ of paraffinic oil/L, and $240 \mathrm{~g}$ of alkoxylated alcohol nonionic surfactants/L; Dow AgroSciences Australia Ltd.) was strategically applied during November and December to minimize summer weeds during establishment. Fertilizer was applied both at sowing (urea, $23 \mathrm{~kg}$ of $\mathrm{N} / \mathrm{ha}$ ) and tactically during autumn and spring. Phosphorus (20 kg/ha), potassium (75 kg/ha), and sulfur $(25 \mathrm{~kg} / \mathrm{ha})$ were applied in March 2012, with diammonium phosphate $(20 \mathrm{~kg}$ of $\mathrm{P} / \mathrm{ha}$ and $18 \mathrm{~kg}$ of $\mathrm{N} / \mathrm{ha}$ ) in April 2012 and superphosphate $(8.8 \mathrm{~kg}$ of P/ ha and $11 \mathrm{~kg}$ of $\mathrm{S} / \mathrm{ha}$ ) in May 2012. Urea was applied during May (28 kg of N/ha) and September (46 kg of N/ha) 2012. Applications of fertilizer totaled 115 $\mathrm{kg}$ of $\mathrm{N} / \mathrm{ha}, 49 \mathrm{~kg}$ of $\mathrm{P} / \mathrm{ha}, 75 \mathrm{~kg}$ of $\mathrm{K} / \mathrm{ha}$, and $36 \mathrm{~kg}$ of $\mathrm{S} /$ ha between establishment and the experimental period.

\section{Cows and Management}

Seventy-two multiparous, predominantly HolsteinFriesian, cows that calved in early to mid winter were used in the experiment (3 per replicate). They were, on average, $136( \pm 30.8 \mathrm{SD})$ DIM (Table 2$)$ and were milked twice daily at ca. 0730 and $1600 \mathrm{~h}$. All cows were weighed and body condition scored on a 1 to 8 scale (Earle, 1976) immediately before the commencement of the experiment. Cows were weighed twice daily postmilking throughout the experiment using automated walk-over scales. Cows were allocated to treatment and replicate using a stratified randomization procedure based on DIM, milk yield, and milk fat concentration (Table 2).

The experiment was conducted over $30 \mathrm{~d}$ (October 5 2012, to November 4, 2012), which included a 6-d uniformity period and a 14-d preexperimental period during which cows were progressively adapted to their respective herbage base. After the preexperimental pe-

Table 2. Mean $( \pm \mathrm{SD})$ DIM, age, BW, and production of milk $(\mathrm{kg} / \mathrm{cow}$ per day), fat $(\mathrm{g} / \mathrm{kg})$, and protein $(\mathrm{g} / \mathrm{kg})$ at the commencement of the experimental period for cows offered 1 of 3 herbage types [chicory monoculture supplemented with alfalfa hay (CHIC+), mixed sward of chicory and perennial ryegrass (MIX), or perennial ryegrass monoculture (PRG)] at 2 allowances: low (20 $\mathrm{kg}$ of DM/cow per day) and high (30 kg of $\mathrm{DM} /$ cow per day)

\begin{tabular}{|c|c|c|c|c|c|c|c|}
\hline Herbage & Allocation & $\begin{array}{c}\text { DIM, } \\
\mathrm{d}\end{array}$ & $\begin{array}{l}\text { Age, } \\
\text { yr }\end{array}$ & $\begin{array}{c}\mathrm{BW}, \\
\mathrm{kg}\end{array}$ & $\begin{array}{l}\text { Milk yield, } \\
\mathrm{kg} / \text { cow per day }\end{array}$ & $\begin{array}{l}\text { Protein, } \\
\text { g/kg }\end{array}$ & $\begin{array}{l}\text { Fat, } \\
\mathrm{g} / \mathrm{kg}\end{array}$ \\
\hline CHIC+ & Low & $136 \pm 31.0$ & $4.7 \pm 1.45$ & $500 \pm 59.8$ & $25.5 \pm 3.39$ & $35.6 \pm 2.89$ & $40.4 \pm 4.86$ \\
\hline MIX & High & $136 \pm 32.0$ & $4.5 \pm 1.04$ & $527 \pm 49.5$ & $26.9 \pm 4.78$ & $33.7 \pm 2.21$ & $38.6 \pm 5.75$ \\
\hline \multirow[t]{2}{*}{ PRG } & Low & $135 \pm 32.0$ & $4.3 \pm 1.65$ & $497 \pm 82.5$ & $26.8 \pm 5.74$ & $34.3 \pm 3.58$ & $38.8 \pm 4.85$ \\
\hline & High & $138 \pm 31.1$ & $4.3 \pm 1.26$ & $528 \pm 72.2$ & $27.9 \pm 3.68$ & $33.4 \pm 2.04$ & $39.0 \pm 7.74$ \\
\hline
\end{tabular}


riod, there was a 10-d measurement period (October 25, 2012 to November 3, 2012) where DMI, nutrient intake, and milk production and composition were measured. During the uniformity period, all cows grazed perennial ryegrass while pellet amounts were adjusted to experimental levels. During the adaptation period, cows were introduced to a mixed sward of chicory and PRG $(7 \mathrm{~d})$, then to their respective experimental diets (7 d).

\section{Feeding Strategies}

Treatment groups of 3 cows were offered their herbage allocation as fresh breaks after each milking (60\% after daytime milking and $40 \%$ after nighttime milking). Each herbage strip within each of the 4 paddocks was divided into 2 parallel sub-strips. The 2 pasture allowances were randomly allocated between the 2 substrips of a given herbage type in each paddock. One group of 3 cows grazed each sub-strip in each of the 4 paddocks, resulting in 6 groups of cows grazing in each paddock and each treatment replicated once in each paddock. Groups of 3 cows were separated from other groups by electric tapes and were prevented from regrazing areas that had been grazed during previous days by the use of back fences.

Alfalfa hay was provided to all $\mathrm{CHIC}+20$ and $\mathrm{CHIC}+30$ groups to reduce the potential for low NDF intakes and associated health disorders by animals on this forage. All cows had ad libitum access to water while grazing via portable troughs located in the area allocated for grazing each day.

\section{Herbage Intake}

Pregrazing herbage mass was estimated every second day by cutting to ground level eight $0.25-\mathrm{m}^{2}$ quadrats along a diagonal transect covering pregrazing areas for both allowances of a given herbage type within each replicate. Samples were weighed, thoroughly mixed, and subsampled before being dried at $100^{\circ} \mathrm{C}$ for measurement of DM concentration and subsequent determination of DM on offer ( $\mathrm{kg}$ of $\mathrm{DM} / \mathrm{ha})$. These values were then used to set grazing areas for the following 2 $\mathrm{d}$ to ensure that animals were allocated the correct area for a given herbage allowance.

Postgrazing herbage mass in each treatment area was measured by cutting to ground level three $0.1-\mathrm{m}^{2}$ quadrats per treatment replicate along a diagonal transect. Samples were washed in cold water to remove soil and foreign material before being dried at $100^{\circ} \mathrm{C}$ for measurement of post-DM yield. This information was used to calculate average herbage DMI for each group (pre-DM yield - post-DM yield).

\section{Supplement Intake}

Pellets were offered in 2 equal meals in the dairy during milking. No refusals of pellets were observed in any group. Alfalfa hay was offered (in long form) in individual feeders $(1,000 \mathrm{~mm}$ diameter $\times 420 \mathrm{~mm}$ deep) for each replicate group of 3 cows in the CHIC+ treatments. Refusals of alfalfa were collected daily and subsampled for analysis of DM and nutritive characteristics by near-infrared spectroscopy (NIRS), which allowed for the calculation of DMI and estimated nutrient intake for each group. It was assumed that there was minimal wastage of alfalfa hay.

\section{Nutritive Characteristics}

Samples of supplementary feeds (alfalfa hay and pellets) were collected daily during the measurement period. For each treatment, samples of pre- and postgrazing herbages were collected daily throughout the measurement period. Each sample (herbage and supplementary feed) was dried at $60^{\circ} \mathrm{C}$ and ground (Foss Cyclotec 1093 Sample Mill; Foss Electric A/S, Hillerød, Denmark) through a 1-mm screen and subsequently analyzed for nutritive characteristics by NIRS. All pre- and postgrazing herbage samples were collected by manually cutting herbage to ground level at a minimum of 10 points along a transect of the respective grazing areas.

Herbage and supplementary feed samples were analyzed at the Department of Environment and Primary Industries by NIRS. Near-infrared spectroscopy spectra were collected on all samples using an XDS Rapid Content Analyzer (Foss Analytical AB, Höganäs, Sweden) in conjunction with WinISI II v.1.04 software (InfraSoft International LLC, Port Matilda, PA). Near-infrared spectroscopy calibrations for $\mathrm{CP}, \mathrm{NDF}$, and in vitro DM digestibility (IVDMD) had previously been derived on large sample populations collected over multiple seasons and using a range of herbages from multiple locations using the procedures of Shenk and Westerhaus (1991). This database comprised close to 800 samples, including chicory, other forages, concentrates, and grains. Standard errors of prediction for $\mathrm{CP}, \mathrm{NDF}$, and IVDMD in herbages were 3.0, 3.6, and $3.8 \%$ DM, respectively. A comparison between NIRS and wet chemistry was undertaken for approximately $10 \%$ of samples, with resultant correlations $\left(\mathrm{R}^{2}\right)$ of 0.90, 0.94, and 0.80 for CP, NDF, and IVDMD, respectively. Reference methods used for NIRS calibrations were as follows: CP using the Kjeldahl method; NDF by the method of Van Soest and Wine (1967), including amylase and sodium sulfite on a DM basis; and IVDMD using a pepsin-cellulase technique (Clarke et al., 1982), with analytical values adjusted using a linear 
regression based on similar samples of known IVDMD. Any spectral outliers from the calibrations had analysis by NIRS repeated, as well as further analysis by wet chemistry techniques. Outliers tended to be the result of improper sample preparation for the NIRS system, and once analysis was repeated, results were within the acceptable range.

Digestible OM in DM (DOMD) was calculated according to using the following formula (CSIRO, 2007):

$$
\operatorname{DOMD}(\%)=7.32+0.84 \operatorname{IVDMD}(\%) \text {. }
$$

Estimated $\mathrm{ME}(\mathrm{MJ} / \mathrm{kg}$ of $\mathrm{DM})$ values were calculated from predicted DOMD values according to using the following formula (CSIRO, 2007):

$$
\mathrm{ME}(\mathrm{MJ} / \mathrm{kg} \text { of } \mathrm{DM})=0.194 \mathrm{DOMD}(\%)-2.577 \text {. }
$$

On d 6 to 8 of the measurement period, corresponding with collection of additional composite milk samples, additional herbage samples cut to ground level were collected. Samples were freeze-dried, ground (Foss Cyclotec 1093 Sample Mill; Foss Electric A/S) through a 1-mm screen, and analyzed for FA composition after toluene extraction, using the method of Sukhija and Palmquist (1988).

\section{Milk Yield and Composition}

The milk yield of each cow was measured at every milking during all periods using a DeLaval Alpro milk metering system (DeLaval International AB, Tumba, Sweden). A composite sample of the milk (p.m. + a.m.) was taken daily throughout the measurement period using inline milk meters (DeLaval International AB). Milk samples were tested for concentrations of protein and fat using an infrared milk analyzer (Bentley 2000; Bentley Instruments Inc., Chaska, MN).

Additional composite samples of milk were taken on 3 consecutive days during the measurement period, proportionately bulked first by cow (p.m. + a.m. samples) and then by weight into replicates (3 cows) and analyzed for FA according to the methods of Feng et al. (2004) and Luna et al. (2005). Protein fractions were also analyzed using the approach of Bordin et al. (2001).

\section{Calculations and Statistical Analysis}

For DMI, nutrient intake, and nutrient selection, values were derived by averaging group means (3 cows) over the treatment period. Differences in nutritive characteristics between pre- and postgrazing forage samples were used to estimate nutrient intakes and nutrient selection during the measurement period.

The amounts of nutrients selected by grazing dairy cows $\left(\mathrm{A}_{\text {sel }} ; \mathrm{g} / \mathrm{kg}\right.$ of $\left.\mathrm{DM}\right)$ were calculated as follows:

$$
\mathrm{A}_{\text {sel }}=\left[\left(\mathrm{M}_{\text {pre }} \times \mathrm{N}_{\text {pre }}\right)-\left(\mathrm{M}_{\text {post }} \times \mathrm{N}_{\text {post }}\right)\right] \text {, }
$$

where $M_{\text {pre }}$ and $M_{\text {post }}$ are the mass of the pre- and postgrazed herbage ( $\mathrm{kg}$ of $\mathrm{DM} / \mathrm{ha}$ ), and $\mathrm{N}_{\text {pre }}$ and $\mathrm{N}_{\text {post }}$ are the concentration of the nutrient (MJ/kg of DM or $\mathrm{g} /$ $\mathrm{kg}$ of $\mathrm{DM}$ ) in the pre- and postgrazed herbage.

Energy-corrected milk, standardized to $4.0 \%$ fat and $3.3 \%$ protein was calculated using the following formula (Tyrrell and Reid, 1965):

$\operatorname{ECM}(\mathrm{kg} /$ cow per day $)=$ milk yield $(\mathrm{kg}) \times$

$[376 \times$ fat $(\%)+209 \times$ protein $(\%)+948] / 3,138$.

Statistical analyses were conducted on measurement period means for each group of 3 cows. For ECM yield, milk yield, milk fat concentration and yield, and protein concentration and yield, values were derived by averaging over the treatment period within cows before averaging over cows within groups. For milk FA and protein fractions, statistical analyses were conducted on means for the $3 \mathrm{~d}$ of sampling, where the sample analyzed represented the bulked milk of 3 cows in the replicate.

All factors were analyzed by ANOVA (GenStat 13; VSN International Ltd., Hemel Hempstead, UK), with factorial treatment structure (split plot, with 3 forage treatments by 2 allowances). This analysis provided 6 residual degrees of freedom for estimating the main effect of herbage type and 9 degrees of freedom for estimating the main effect of herbage allowance and estimating interaction effects.

\section{RESULTS}

Pregrazing herbage mass averaged $( \pm \mathrm{SD}) \quad 5,413$ $( \pm 750) \mathrm{kg}$ of $\mathrm{CHIC}+\mathrm{DM} / \mathrm{ha}, 5,436( \pm 876) \mathrm{kg}$ of MIX DM/ha, and 5,735 ( \pm 518$) \mathrm{kg}$ of PRG DM/ha. Postgrazing herbage mass averaged 2,659 $( \pm 733) \mathrm{kg}$ of CHIC+ DM/ha, 2,298 $( \pm 640) \mathrm{kg}$ of MIX DM/ha, and $2,639( \pm 709) \mathrm{kg}$ of PRG DM/ha. Utilization averaged $51 \% \mathrm{CHIC}+, 57 \%$ MIX, and 54\% PRG.

Herbage DMI (Table 3) was lowest $(P=0.015)$ for animals in the CHIC+ treatments compared with both the MIX and PRG treatments. Total DMI also differed $(P=0.021)$ between herbage types. Intake of $\mathrm{CP}$ and estimated ME was not affected by herbage type. Intake of NDF was lower $(P<0.001)$ in the CHIC+ 
treatments than either the MIX and PRG treatments. The target allowance at each of the herbage levels was 20 and $30 \mathrm{~kg}$ of $\mathrm{DM} / \mathrm{cow}$ per day and the measured herbage allowances were 20.9 and $31.4 \mathrm{~kg}$ of $\mathrm{DM} /$ cow per day. Pregrazing herbage allowance was $5,528 \mathrm{~kg}$ of $\mathrm{DM} /$ ha for both low and high allowances, whereas postgrazing herbage averaged 2,058 $( \pm 518) \mathrm{kg}$ of DM/ ha for the low allowance and 3,006 $( \pm 544) \mathrm{kg}$ of DM/ha for the high allowance. Utilization (\% of feed on offer consumed) averaged $46 \%$ for the high allowance and $63 \%$ for the low allowance.

The higher herbage allowance increased intake of herbage by, on average, about $1 \mathrm{~kg} /$ cow per day (Table $3)$. However, this effect differed with herbage type (Table 3) and was also reflected in total intake (Table 3). Although DMI of all herbages increased $(P<0.001)$ at the high allowance, the magnitude of the increase was least for the CHIC+ treatment. Crude protein concentration in the herbage consumed was higher at the high allowance, whereas NDF concentration was higher at the low allowance. Increasing from low to high herbage allowance did not increase selection of estimated ME from herbage

Herbage type (Table 3) did not affect any of the measured milk production parameters (milk yield, milk solids yield, milk fat and protein concentrations, and total output or yield of ECM). Increasing herbage allowance (Table 3$)$ increased $(P=0.032)$ milk protein concentration and daily milk protein output $(\mathrm{g} / \mathrm{d})$. Milk protein concentration increased from 3.23 to $3.34 \%$ with the increase in herbage allowance.

Herbage FA concentrations are presented in Table 1. Chicory had higher concentrations of cis-9 C16:0, C18:1, C18:2n-6, and C22:0 FA and lower concentrations of C17:0 and C18:0 compared with the PRG and MIX diets. The C18:0 concentration was highest for the PRG treatment. Concentrations of FA in the alfalfa hay tended to be lower than in the grazed herbages. The pellets contained higher concentrations of $\mathrm{C} 16: 0$, cis- 9 C18:1, and C18:2n- 6 than any of the herbage sources.

Herbage source affected concentrations of milk FA (Table 4). Milk from CHIC+ cows had higher concentrations of $\mathrm{C} 10: 1, \mathrm{C} 18: 2 \mathrm{n}-6, \mathrm{C} 18: 3 \mathrm{n}-3$, and $\mathrm{C} 22: 5$ than PRG or MIX cows. Milk from PRG-fed cows was higher in iso C15, C15:0, and C18:0. Total SFA concentration did not differ $(P=0.13)$ between herbage types. However, total MUFA concentrations were higher $(P=$ 0.024) for the MIX and PRG than CHIC+ treatment. Total PUFA concentrations were higher $(P=0.007)$ in milk from CHIC+ cows (3.9 compared with 3.4 and 2.9 $\mathrm{g} / 100 \mathrm{~g}$ of FA for MIX and PRG, respectively). Total de novo synthesized FA concentrations were higher $(P$ $=0.025)$ for CHIC + than PRG and MIX treatments.
Total C18 FA concentration was higher in the MIX and PRG treatments than in the CHIC+ treatment.

Less effect was observed of herbage allowance on milk FA concentrations (Table 4) than of herbage source. Total SFA, MUFA, and PUFA concentrations did not differ between herbage allowances. Concentrations of C12:0 and trans-9 C18:1 to cis-6 C18:1 were higher in the milk of cows offered the high allowance (all herbage types). Concentrations of $\mathrm{C} 4: 0$, iso $\mathrm{C} 15$, anteiso $\mathrm{C} 17$, and C20:0 were higher in cows offered the low allowance. An interaction between herbage type and allowance was observed for C8:0 $(P=0.024), \mathrm{C} 10: 1(P$ $=0.030)$, and $\mathrm{C} 22: 5(P=0.045) \mathrm{FA}$.

Herbage type did not affect the concentration of measured milk protein fractions (Table 5), whereas increased herbage allowance increased the concentrations of $\kappa$-CN (6.55 compared with $6.09 ; P=0.002)$ and total casein (43.6 compared with $41.7 ; P=0.013$ ) compared with the low herbage allowance. Effect of allowance on milk protein concentrations were consistent between herbage types.

\section{DISCUSSION}

The hypothesis that cows grazing a monoculture of chicory (supplemented with alfalfa hay and concentrate pellets) or a mixture of chicory and perennial ryegrass (supplemented with concentrate pellets) would produce more milk than those fed perennial ryegrass and pellets was not sustained under the conditions of this experiment. In southwest Victoria (Australia), Chapman et al. (2008) observed an increase in milk yield associated with an increase in herbage DMI from a summer active mixed sward, containing a significant proportion ( $\sim 80 \%)$ of chicory. Consistent with this, Waugh et al. (1998) and Li and Kemp (2005) observed increased milk yields associated with supplementing dairy cow diets with chicory.

In the current experiment, the intake of chicory herbage was lower than for the mixed or perennial ryegrass herbage, due at least in part to substitution of alfalfa hay for grazed herbage. Substitution rates of supplements for herbage generally vary between 0 and $1.0 \mathrm{~kg}$ of DM reduction in herbage intake per kilogram of DM increase in supplement intake (Stockdale, 2000) and are higher for herbages than concentrate supplements (Stockdale, 2000). As total herbage intake (herbage + hay) was similar across the 3 herbage treatments and cows were receiving $6 \mathrm{~kg}$ of pellet $\mathrm{DM} / \mathrm{d}$, it is likely that the substitution rate of alfalfa hay for chicory approached $1.0 \mathrm{~kg}$ of DM/ $\mathrm{kg}$ of DM. Visual observations indicated that when cows were moved back to their chicory paddocks following milking they tended to con- 
Table 3. Effect of offering 1 of 3 herbage types [chicory monoculture supplemented with alfalfa hay (CHIC+), mixed sward of chicory and perennial ryegrass (MIX), or perennial ryegrass monoculture (PRG)] at 2 herbage allowances [low (L): 20 or high (H): $30 \mathrm{~kg}$ of DM/cow per day] on DM and nutrient intake and milk production and composition of mid-lactation dairy cows

\begin{tabular}{|c|c|c|c|c|c|c|c|c|c|c|c|c|}
\hline \multirow[b]{3}{*}{ Item } & \multicolumn{6}{|c|}{ Treatment } & \multicolumn{6}{|c|}{ Effect $^{1}$} \\
\hline & \multicolumn{2}{|c|}{$\mathrm{CHIC}+$} & \multicolumn{2}{|c|}{ MIX } & \multicolumn{2}{|c|}{ PRG } & \multicolumn{2}{|c|}{ Forage } & \multicolumn{2}{|c|}{ Allowance } & \multicolumn{2}{|c|}{ Interaction } \\
\hline & $\mathrm{L}$ & $\mathrm{H}$ & $\mathrm{L}$ & $\mathrm{H}$ & $\mathrm{L}$ & $\mathrm{H}$ & SED & $P$-value & SED & $P$-value & SED & $P$-value \\
\hline Herbage DMI, $\mathrm{kg}$ of DM/cow per day & 12.5 & 13.1 & 13.1 & 14.9 & 13.4 & 14.5 & 0.31 & 0.015 & 0.15 & $<0.001$ & 0.25 & 0.026 \\
\hline Pellet DMI, $\mathrm{kg}$ of DM/cow per day & 5.9 & 5.9 & 5.9 & 5.9 & 5.9 & 5.9 & - & - & - & - & - & - \\
\hline Alfalfa DMI, $\mathrm{kg}$ of DM/cow per day & 2.2 & 2.2 & - & - & - & - & - & - & - & - & - & - \\
\hline Total DMI, $\mathrm{kg}$ of DM/cow per day & 20.7 & 21.3 & 19.0 & 20.8 & 19.3 & 20.5 & 0.31 & 0.021 & 0.14 & $<0.001$ & 0.25 & 0.023 \\
\hline $\mathrm{CP}, \mathrm{g} / \mathrm{kg}$ of $\mathrm{DM}$ & 163 & 181 & 169 & 207 & 167 & 196 & 15.3 & 0.61 & 59.9 & 0.001 & 10.4 & 0.44 \\
\hline $\mathrm{NDF}, \mathrm{g} / \mathrm{kg}$ of DM & 257 & 183 & 408 & 341 & 498 & 435 & 196.6 & $<0.001$ & 10.2 & $<0.001$ & 17.8 & 0.73 \\
\hline Estimated ME, MJ $/ \mathrm{kg}$ of $\mathrm{DM}$ & 11.9 & 11.9 & 11.5 & 12.1 & 11.9 & 12.2 & 0.38 & 0.76 & 0.38 & 0.38 & 0.52 & 0.68 \\
\hline \multicolumn{13}{|l|}{ Nutrient intake } \\
\hline $\mathrm{CP}, \mathrm{g} /$ cow per day & 3,309 & 3,656 & 3,112 & 3,954 & 3,119 & 3,717 & 251.9 & 0.90 & 80.7 & $<0.001$ & 139.9 & 0.093 \\
\hline NDF, g/cow per day & 5,197 & 4,397 & 6,309 & 6,036 & 7,472 & 7,257 & 254.7 & $<0.001$ & 154.3 & 0.021 & 267.3 & 0.28 \\
\hline Estimated ME, MJ/cow per day & 245 & 251 & 228 & 258 & 237 & 254 & 7.7 & 0.80 & 3.8 & 0.001 & 6.5 & 0.094 \\
\hline \multicolumn{13}{|l|}{ Milk production } \\
\hline Milk yield, kg & 28.5 & 27.5 & 27.1 & 29.8 & 27.2 & 28.0 & 0.80 & 0.60 & 0.70 & 0.26 & 1.21 & 0.15 \\
\hline Milk solids yield, $\mathrm{kg}$ & 1.91 & 1.93 & 1.93 & 2.00 & 1.80 & 1.97 & 0.067 & 0.51 & 0.051 & 0.12 & 0.089 & 0.54 \\
\hline Milk fat, $\%$ & 3.58 & 3.72 & 3.89 & 3.42 & 3.54 & 3.78 & 0.076 & 0.99 & 0.118 & 0.78 & 0.204 & 0.075 \\
\hline Milk protein, $\%$ & 3.22 & 3.37 & 3.30 & 3.31 & 3.18 & 3.37 & 0.059 & 0.90 & 0.046 & 0.032 & 0.079 & 0.30 \\
\hline $\mathrm{ECM}, \mathrm{kg}$ & 26.9 & 26.7 & 26.7 & 27.8 & 25.6 & 27.4 & 0.87 & 0.67 & 0.65 & 0.22 & 1.13 & 0.48 \\
\hline $\mathrm{ECM} / \mathrm{kg}$ of DMI & 1.38 & 1.29 & 1.42 & 1.43 & 1.41 & 1.37 & 0.026 & 0.036 & 0.034 & 0.29 & 0.059 & 0.53 \\
\hline $\mathrm{N}$ efficiency (milk $\mathrm{N} / \mathrm{N}$ consumed) & 0.27 & 0.25 & 0.28 & 0.25 & 0.27 & 0.25 & 0.018 & 0.97 & 0.008 & 0.007 & 0.013 & 0.62 \\
\hline
\end{tabular}

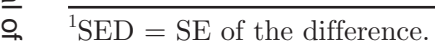


Table 4. Effect of herbage type [chicory monoculture supplemented with alfalfa hay (CHIC+), mixed sward of chicory and perennial ryegrass (MIX), or perennial ryegrass monoculture (PRG)] and herbage allowance [low (L): 20 or high (H): $30 \mathrm{~kg}$ of DM/cow per day] on milk FA composition $(\mathrm{g} / 100 \mathrm{~g}$ of $\mathrm{FA})$

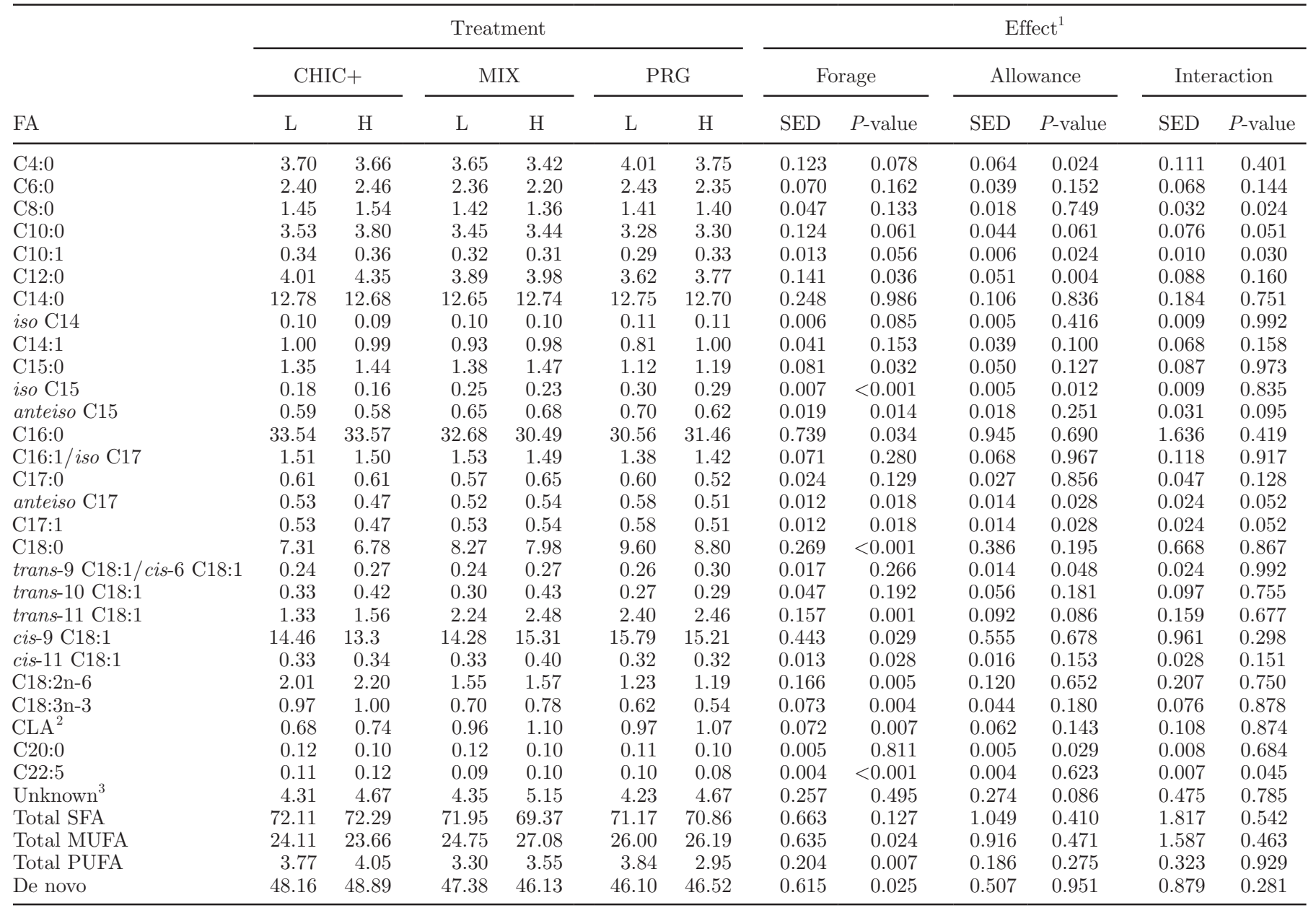

${ }^{1} \mathrm{SED}=\mathrm{SE}$ of the difference.

${ }^{2}$ Conjugated linoleic acid (CLA) reported is cis-9,trans-11 CLA; trans-10,cis-12 CLA is present but is below the detection threshold.

${ }^{3}$ Unknown includes isomers of C18:1, C18:2, C14:1, and C16:1 present below the detection threshold.

Table 5. Effect of herbage type [chicory monoculture supplemented with alfalfa hay (CHIC+), mixed sward of chicory and perennial ryegrass (MIX), or perennial ryegrass monoculture (PRG)] and allowance [low (L): 20 or high (H): $30 \mathrm{~kg}$ of DM/cow per day] on milk protein composition $(\mathrm{mg} / \mathrm{g})$

\begin{tabular}{|c|c|c|c|c|c|c|c|c|c|c|c|c|}
\hline \multirow[b]{2}{*}{ Item } & \multicolumn{6}{|c|}{ Treatment } & \multicolumn{6}{|c|}{ Effect $^{1}$} \\
\hline & $\mathrm{L}$ & $\mathrm{H}$ & $\mathrm{L}$ & $\mathrm{H}$ & $\mathrm{L}$ & $\mathrm{H}$ & SED & $P$-value & SED & $P$-value & SED & $P$-value \\
\hline$\kappa-\mathrm{CN}$ & 6.09 & 6.79 & 6.03 & 6.32 & 6.14 & 6.52 & 0.254 & 0.60 & 0.103 & 0.002 & 0.178 & 0.29 \\
\hline$\alpha_{\mathrm{S}^{2}} \mathrm{CN}$ & 8.57 & 9.15 & 9.36 & 9.08 & 8.2 & 9.55 & 0.271 & 0.44 & 0.341 & 0.30 & 0.590 & 0.42 \\
\hline$\alpha_{S_{1}-}-C N$ & 12.57 & 13.22 & 12.43 & 12.65 & 11.94 & 12.96 & 0.407 & 0.55 & 0.316 & 0.075 & 0.547 & 0.61 \\
\hline$\alpha-L G$ & 1.86 & 1.82 & 1.71 & 1.88 & 1.66 & 1.80 & 0.075 & 0.38 & 0.057 & 0.15 & 0.098 & 0.31 \\
\hline$\beta-L G$ B & 2.23 & 2.51 & 1.66 & 1.78 & 1.45 & 1.85 & 0.598 & 0.46 & 0.425 & 0.55 & 0.736 & 0.96 \\
\hline$\beta-\mathrm{LG} \mathrm{A}$ & 2.34 & 2.48 & 3.31 & 3.02 & 3.41 & 2.93 & 0.855 & 0.62 & 0.704 & 0.77 & 1.220 & 0.94 \\
\hline Total whey & 6.43 & 6.81 & 6.69 & 6.68 & 6.52 & 6.58 & 0.280 & 0.90 & 0.270 & 0.60 & 0.468 & 0.83 \\
\hline
\end{tabular}

${ }^{1} \mathrm{SED}=\mathrm{SE}$ of the difference. 
sume the offered alfalfa hay before grazing the chicory, which may have led to a reduced capacity to consume the chicory.

When the DM content of herbage is less than $150 \mathrm{~g} /$ $\mathrm{kg}$ of DM, intake may be reduced (John and Ulyatt, 1987). This was suggested by Tinworth et al. (1999) and Collins and McCoy (1997) to be a potential factor limiting chicory intake. This effect was not observed by Minnee et al. (2012), even with a DM content lower than $150 \mathrm{~g} / \mathrm{kg}$ for both chicory and plantain herbages. In the present study, the chicory herbage had a DM concentration of $100 \mathrm{~g} / \mathrm{kg}$ and this may have limited intake. However, the DM concentration of the other herbage types (MIX: $120 \mathrm{~g} / \mathrm{kg}$; PRG: $160 \mathrm{~g} / \mathrm{kg}$ ) suggests that herbage DM content may not have been the primary factor limiting intake of herbage.

In concert with the low DM concentration, the low NDF concentration of chicory may have also posed a limitation to intake. Waugh et al. (1998) reported that a combination of low soluble carbohydrate levels with low ADF and NDF concentrations may have resulted in lower milk yield from chicory (compared with turnips); however, intake was not reported. In the current study, milk yield was not compromised by the lower NDF concentration in the consumed feed in either the low or high allowance of chicory, suggesting that the chicory sward could have potentially been offered without the supplementary alfalfa hay as a source of NDF, despite total diet NDF concentration being substantially lower than that recommended for dairy cows (300 to $400 \mathrm{~g} / \mathrm{kg}$ DM; Standing Committee on Agriculture, 1990; Wales et al., 2006). Total NDF concentration in the MIX diet (Table 2), although lower than PRG, was within the target range (300 to $400 \mathrm{~g} / \mathrm{kg}$ of DM) and potentially enabled DMI to be maintained in the cows offered the MIX diet.

In this experiment, milk yield and the yield of milk constituents (fat and protein) did not differ between herbage types. Consistent with this finding is the lack of significant difference in the intake of $\mathrm{CP}$ and ME. However, Minnee et al. (2012) reported that supplementing a perennial ryegrass diet with chicory or plantain was only associated with an increase in milk solids yield (above PRG) when estimated ME of the perennial ryegrass was low. In the current study, estimated ME of all herbages was similar and high (above $11 \mathrm{MJ} / \mathrm{kg}$ of DM). The potential of chicory to increase milk yield during spring (moderate to high ryegrass ME) is perhaps more limited than during periods where ryegrass ME is low (summer/autumn). However, feeding chicory or a mixed sward in spring when the ME of perennial ryegrass was high did not have a negative effect on milk yield or composition.
The hypothesis that offering these 3 diets at a higher herbage allowance would increase milk production through increases in DM and nutrient intake, irrespective of herbage type, was sustained in part. Increasing herbage allowance from 20 to $30 \mathrm{~kg}$ of $\mathrm{DM} /$ cow per day increased herbage DMI in all herbage types, although the magnitude of effect differed between herbage types. Herbage DMI at the higher allowance increased by 0.6 $\mathrm{kg} /$ cow per day in the CHIC+, 1.1 in the PRG, and 1.9 for the MIX. These differences indicate that some restrictions may exist in the level of chicory that can be consumed and is considered to be due to low DM, or development of subclinical acidosis associated with low NDF concentrations.

The increase in herbage DMI with increasing allowance of PRG was only $1.1 \mathrm{~kg}$ of $\mathrm{DM} / \mathrm{d}$. This is a lower increase than reported for cows grazing irrigated PRG pasture at allowances of 20 or $30 \mathrm{~kg}$ of $\mathrm{DM} /$ cow per day in spring $(1.8 \mathrm{~kg}$ of $\mathrm{DM} / \mathrm{d})$ or autumn $(2.6 \mathrm{~kg}$ of $\mathrm{DM} / \mathrm{d}$ ) where cows were not receiving grain supplements (Wales et al., 1998). In a separate experiment, Wales et al. (1998) found that grain supplementation reduced the response in herbage intake to increasing allowance.

Surprisingly, cows offered the higher herbage allowance did not have higher milk production than the cows at the lower allowance. However, milk protein concentration $(\mathrm{g} / \mathrm{kg} ; P=0.046)$ and daily milk protein output (g/cow per day) increased with the increased herbage allowance. As well as resulting in higher DMI, increasing herbage allowance from 20 to $30 \mathrm{~kg}$ of $\mathrm{DM} /$ cow per day enabled greater selection for nutritive characteristics, which is likely to have resulted in the increase in milk protein concentration.

The hypothesis that replacing PRG in the diet with chicory would influence milk fat and protein composition was sustained in part. Including chicory in the diet affected milk FA composition, but milk protein composition was influenced by herbage allowance rather than herbage type. For consumers, key targets in manipulating milk FA are the reduction of medium-chain SFA and an increase in conjugated linoleic acids (CLA) and PUFA (Dewhurst et al., 2006). Saturated fatty acids have been linked to heart disease, whereas CLA and C4:0 (butyric acid) are considered beneficial for human health, including having anticarcinogenic, antiatherogenic, and antiobesity properties (Chilliard et al., 2001; Stockdale et al., 2003; Dunshea et al., 2008). Fatty acid composition also affects physical properties such as melting point and hardness of butter (Chilliard et al., 2001).

Conjugated linoleic acid concentration in milk was significantly affected by pasture type, with a lower 
concentration in milk from cows offered chicory. Concentration of CLA in milk is generally higher from animals consuming pasture, compared with conserved herbages and concentrates (Wales et al., 2006; Dunshea et al., 2008). Concentrations of CLA and vaccenic acid (trans-11 C18:1) in milk have been attributed to nutritive value and quantity of pasture (Dewhurst et al., 2006). The decrease in CLA associated with the $\mathrm{CHIC}+$ diet in the current study cannot entirely be apportioned to chicory, due to the inclusion of alfalfa hay in the diet. Hay making greatly decreases the concentrations of FA, including CLA (Chilliard et al., 2001) compared with both silage and fresh herbage; therefore, inclusion of the alfalfa hay is likely to have contributed to the decrease in CLA.

Medium-chain FA, including C12:0, C14:0, and C16:0, account for the majority of SFA in milk (Dewhurst et al., 2006). In the current study, no significant effect was observed of herbage type (or allowance) on SFA, although C16:0 were higher in milk from CHIC+-fed cows. Individual PUFA, primarily linoleic (C18:2n-6) and $\alpha$-linolenic acid (C18:3n-3), and total PUFA were increased by the inclusion of chicory in the diet. Forages have been observed to influence both MUFA and PUFA, with grazed herbage tending to increase PUFA compared with silage or concentrate feeds (Dewhurst et al., 2006). The higher concentration of C18:2n-6 observed in the MIX and CHIC+ herbage was consistent with increased linoleic acid and total PUFA in milk, indicating potential benefits of chicory herbage on PUFA concentrations.

The increase in $\kappa$-CN and total casein content with increased herbage intake may affect milk processing efficiency; for example, in cheese manufacture (Walker et al., 2007). The lack of differences between herbage types in concentrations of milk proteins suggests that chicory or a mixed sward could be used as an alternative to perennial ryegrass without a negative effect on manufacturing quality.

\section{CONCLUSIONS}

Although feeding the CHIC + diet (chicory plus alfalfa hay) or the MIX diet did not increase milk yield and intake compared with PRG as hypothesized, this experiment has demonstrated that chicory can be used as an alternative herbage base to PRG in spring for mid-lactation cows. The MIX diet appeared to result in a similar response to PRG without the need to provide an NDF supplement. However, management requirements of chicory and PRG are different (timing of grazing and level of desirable postgrazing residual), making management of such a mixed sward complex compared with managing each species alone. Offering an increased allowance of all herbages resulted in a small increase in herbage DMI, but contrary to expectations, the higher allowance only increased milk protein concentration.

\section{ACKNOWLEDGMENTS}

The authors are grateful to K. Rentsch, S. Burch, J. Hollier, and M. Brophy [Department of Environment and Primary Industries (DEPI), Horsham, Victoria, Australia], and DemoDAIRY (Terang, Victoria, Australia) farm staff for technical assistance. Analysis of milk and herbage fatty acids and milk protein fractions were undertaken at AgResearch (Ruakura Research Centre, Hamilton, New Zealand). Herbage and supplement samples were analyzed for nutritive value using NIRS at DEPI. This research was funded by the Victorian DEPI and Dairy Australia (Melbourne, Victoria, Australia).

\section{REFERENCES}

Bordin, G., F. Cordeiro Raposo, B. de la Calle, and A. R. Rodriguez. 2001. Identification and quantification of major bovine milk proteins by liquid chromatography. J. Chromatogr. A 928:63-76.

Chapman, D. F., J. L. Jacobs, G. N. Ward, G. B. O'Brien, S. N. Kenny, D. Beca, and F. R. McKenzie. 2006. Forage supply systems for dryland dairy farms in southern Australia. Proc. NZ Grassl. Assoc. 68:255-260.

Chapman, D. F., J. Tharmaraj, and Z. N. Nie. 2008. Milk-production potential of different sward types in a temperate southern Australian environment. Grass Forage Sci. 63:221-233.

Chilliard, Y., A. Ferlay, and M. Doreau. 2001. Effect of different types of forages, animal fat or marine oils in cow's diet on milk fat secretion and composition, especially conjugated linoleic acid (CLA) and polyunsaturated fatty acids. Livest. Prod. Sci. 70:31-48.

Clarke, T., P. C. Flinn, and A. A. McGowan. 1982. Low-cost pepsincellulase assays for prediction of digestibility of herbage. Grass Forage Sci. 37:147-150.

Collins, M., and J. E. McCoy. 1997. Chicory productivity, forage quality and response to nitrogen fertilization. Agron. J. 89:232-238.

CSIRO. 2007. Nutrient Requirements of Domesticated Ruminants. M. Freer, H. Dove, and J. V. Nolan, ed. CSIRO Publ., Melbourne, Victoria, Australia.

Dewhurst, R. J., K. J. Shingfield, M. R. F. Lee, and N. D. Scollan. 2006. Increasing the concentrations of beneficial polyunsaturated fatty acids in milk produced by dairy cows in high-forage systems. Anim. Feed Sci. Technol. 131:168-206.

Doyle, P. T., C. R. Stockdale, A. R. Lawson, and D. C. Cohen. 2000. Pastures for Dairy Production in Victoria. 2nd ed. Department of Natural Resources and Environment, Victoria, Australia.

Dunshea, F. R., G. P. Walker, E. Ostrowska, and P. T. Doyle. 2008. Seasonal variation in the concentration of conjugated linoleic and trans fatty acids in milk fat from commercial dairy farms is associated with pasture and grazing management and supplementary feeding practices. Aust. J. Exp. Agric. 48:1062-1075.

Earle, D. F. 1976. A guide to scoring dairy cow condition. J. Agric. (Victoria) 74:228-231.

Feng, S., A. L. Lock, and P. C. Garnsworthy. 2004. Technical note: A rapid lipid separation method for determining fatty acid composition of milk. J. Dairy Sci. 87:3785-3788.

John, A., and M. J. Ulyatt. 1987. Importance of dry matter content to the voluntary feed intake of fresh grass forages. Proc. NZ Soc. Anim. Prod. 47:13-16.

Li, G., and P. D. Kemp. 2005. Forage chicory (Cichorium intybus L.): A review of its agronomy and animal production. Adv. Agron. $88: 187-222$. 
Luna, P., M. Juarez, and M. A. de la Fuente. 2005. Validation of a rapid milk fat separation method to determine the fatty acid profile by gas chromatography. J. Dairy Sci. 88:3377-3381.

Minnee, E. M. K., C. E. F. Clark, T. B. McAllister, K. J. Hutchinson, and J. M. Lee. 2012. Chicory and plantain as feeds for dairy cows in late lactation. Pages 426-428 in Proc. Australasian Dairy Sci. Symp., Melbourne, Australia. Department of Primary Industries, Melbourne, Victoria, Australia.

National Health and Medical Research Council. 2004. Australian Code of Practice for the Care and Use of Animals for Scientific Purposes. 7th ed. Australian Government, Canberra, Australia.

Shenk, J. S., and M. O. Westerhaus. 1991. Population definition, sample selection and calibration procedures for near infrared reflectance spectroscopy . Crop Sci. 31:469-474.

Standing Committee on Agriculture. 1990. Feeding Standards for Australian livestock: Ruminants. CSIRO, Melbourne, Victoria, Australia.

Stockdale, C. R. 2000. Levels of pasture substitution when concentrates are fed to grazing dairy cows in northern Victoria. Aust. J. Exp. Agric. 40:913-921.

Stockdale, C. R., G. P. Walker, W. J. Wales, D. E. Dalley, A. Birkett, Z. Shen, and P. T. Doyle. 2003. Influence of pasture and concentrates in the diet of grazing dairy cows on the fatty acid composition of milk. J. Dairy Res. 70:267-276.

Sukhija, P. S., and D. L. Palmquist. 1988. Rapid method for determination of total fatty acid content and composition of feedstuffs and feces. J. Agric. Food Chem. 36:1202-1206.
Tinworth, T. R. H., T. N. Barry, and P. R. Wilson. 1999. The effect of wilting chicory on its voluntary feed intake and digestion by red deer. J. Agric. Sci. 133:217-221.

Tyrrell, H. F., and J. T. Reid. 1965. Prediction of the energy value of cow's milk. J. Dairy Sci. 48:1215-1223.

Van Soest, P. J., and R. H. Wine. 1967. Use of detergents in the analysis of fibrous feeds. IV. Determination of plant cell wall constituents. J. AOAC 50:50-55.

Waghorn, G. C., and D. A. Clark. 2004. Feeding value of pastures for ruminants. N. Z. Vet. J. 52:320-331.

Wales, W. J., P. T. Doyle, and D. W. Dellow. 1998. Dry matter intake and nutrient selection by lactating cows grazing irrigates pastures at different pasture allowances in summer and autumn. Aust. J. Exp. Agric. 38:451-460

Wales, W. J., J. W. Heard, C. K. M. Ho, C. M. Leddin, C. R. Stockdale, G. P. Walker, and P. T. Doyle. 2006. Profitable feeding of dairy cows on irrigated dairy farms in northern Victoria. Aust. J. Exp. Agric. 46:743-752.

Walker, G. P., R. Williams, P. T. Doyle, and F. R. Dunshea. 2007. Seasonal variation in milk production and cheese yield from commercial dairy farms located in northern Victoria is associated with pasture and grazing management and supplementary feeding practices. Aust. J. Exp. Agric. 47:509-524.

Waugh, C. D., D. A. Clark, S. L. Harris, E. R. Thom, P. J. A. Copeman, and A. R. Napper. 1998. Chicory for milk production. Proc. NZ Grassl. Assoc. 60:33-37. 